\title{
Fred Ferguson and Graffiti: Fresh Paint
}

\section{Shavincia J. Thomas The College of The Bahamas Alumna ${ }^{1}$}

Living up to its name, the CD Fresh Paint certainly introduces a revamp to Bahamian favourites. Performed by Fred Ferguson and Graffiti, this exciting CD quickly captures the attention of listeners.

Growing up on Crooked Island, Bahamas at a time when there was only one radio station in all The Bahamas, Fred Ferguson was constantly exposed to the rake n' scrape music they played and it became Ferguson's favourite genre of music. During his life, Fred was employed at a few places such as Batelco and Barclays Bank, but none of these proved to be as fulfilling as his job of passion. Owing to his love for listening to and playing rake n' scrape music, he became a performing and recording artist, allowing him to secure a position as an Entertainment Consultant at the Ministry of Tourism. Ferguson was commissioned by the Ministry of Tourism to create the CD, Fresh Paint and had the liberty to select the songs that he wanted to include. $\mathrm{He}$ chose 10 selections - nine popular Bahamian pieces and one of his original compositions (F. Ferguson, personal communication, September 29, 2013).

The CD opens with the well-known piece, "Funky Nassau", composed by Raphael Munnings and Tyrone Fitzgerald. While staying true to the original's driving beat, this rendition lays underneath it a pulsating Junkanoo rhythm. There are no lead vocals on the entire $\mathrm{CD}$, only back-up vocals. The instrumentalists do such an excellent job of syncopating the melody that you can almost hear their instruments sing the lyrics.

Next on the $C D$ is another very popular Bahamian piece, "Bangaley", written by Charlie Adamson. "Bangaley" tells the tale of a man who left his mother's house to live with a woman he loved, only to discover one day that the woman was cheating on him. Not only did this woman cheat on the man but also her "sweetheart" was wearing the man's pajamas and shoes! This would throw anyone into despair, hence the refrain: "Bangaley show me ya motion, Bangaley jump in the ocean!" Ferguson and his dynamic band captured the emotion of this piece. On this recording, the tempo is slightly faster than typically played but still rhythmically exciting. As each musician takes a solo and delves further into the melody, the recurring theme of "Bangaley show me ya motion" can still be heard, even without sung lyrics. The trumpet, euphonium, and saxophone solos, arranged masterfully with just the right accompaniment, flare at just the right times.

Next up, and slowing down the CD's tempo a bit, is the Charles Lofthouse song "Bahama

\footnotetext{
${ }^{1}$ Shavincia J. Thomas, Alumna, The College of The Bahamas.

Acknowledgments: The author would like to thank Dr. Christine Gangelhoff for her assistance. E-mail: shavinciathomas122@hotmail.com

APA reference: Thomas, S. J. (2013). Fred Ferguson and Graffiti: Fresh Paint. The International Journal of Bahamian Studies, 19(2), 93-94. https://doi.org/10.15362/ijbs.v19i2.194
} 
Lullaby". Although the first chord and continuing rhythm is deceptively similar to Anita Baker's "Been So Long", the saxophone takes us on a different melodic journey. Out of all of the songs on the CD, this one is the farthest from what is known as the Bahamian style of arranging, particularly when it comes to the accompaniment. It is this different melodic journey that makes this CD feel "fresh."

The song, "Out on the Beach", provides a similar feel. The next song, "Day Break", puts us back on track with the cultural idiosyncrasies of Bahamian music, characteristics also significantly displayed in the track, "Spence for Da Soul". Possessing a typical rake n' scrape form, this track pays tribute to the iconic Bahamian guitarist and singer Joseph Spence. $\mathrm{He}$ is one of the world's best-known Bahamian musicians. Spence received musical training from his uncle in Andros, and further expanded his musical repertoire when he served as a contract worker in the United States during and after World War II. The effortless playing style of Joseph Spence is what attracted music historians Sam Charters and Alan Lomax to record his playing. He was even asked to make guest appearances at Carnegie Hall, offers he declined. Spence's peculiar way of playing the guitar - playing in drop D chords while simultaneously playing an accompanying bass line, and singing almost as if he were grunting - made him uniquely popular among many (Justilien, 2004). Fred Ferguson believes that Spence is a dynamic Bahamian artist who is severely underrated in The Bahamas (F. Ferguson, personal communication, September 29, 2013). This is why Ferguson chose to highlight Spence on this CD.

To describe each and every song on the CD would essentially be a spoiler for those intending to purchase the CD. One must listen to the $\mathrm{CD}$ to truly appreciate its unique flare and charm. The album covers some well-known and well-loved pieces specific to Bahamian cultural tradition. With its new and lively approach to Bahamian classics, this album is bound to capture the wider listening audience, especially considering the rising trend of popular music in the country. With this in mind, the CD Fresh Paint certainly lives up to its cover label, "a new TWIST on Bahamian favourites".

\section{REFERENCES}

Justilien, C. (2004). Musicians and entertainers of The Bahamas: Joseph

Spence. Retrieved from

http://www.bahamasentertainers.com/Artis

t/JosephSpence/spence_bio.html 